Tolerance of Impatiens balsamina L.,

and Crotalaria retusa $L$. to grow on soil contaminated by used lubricating oil: $A$ comparative study

\title{
Gamage, W
}

http://hdl.handle.net/10026.1/15147

10.1016/j.ecoenv.2019.109911

Ecotoxicology and Environmental Safety

Elsevier BV

All content in PEARL is protected by copyright law. Author manuscripts are made available in accordance with publisher policies. Please cite only the published version using the details provided on the item record or document. In the absence of an open licence (e.g. Creative Commons), permissions for further reuse of content should be sought from the publisher or author. 


\title{
Tolerance of Impatiens balsamina L., and Crotalaria retusa L. to grow on soil contaminated by used lubricating oil: A comparative study
}

\author{
Walakulu Gamage ${ }^{\mathrm{a}}$, Kanaji Masakorala ${ }^{\mathrm{a}, *}$, Murray T. Brown ${ }^{\mathrm{b}}$, Widana Gamage ${ }^{\mathrm{a}}$

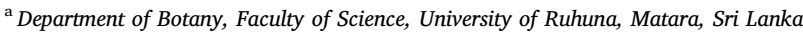 \\ ${ }^{\mathrm{b}}$ School of Biological and Marine Sciences, University of Plymouth, Drake Circus, Plymouth, United Kingdom
}

\section{A R T I C L E I N F O}

\section{Keywords:}

I. balsamina L.

C. retusa $\mathrm{L}$.

Phytoremediation

Tolerance

Used lubricating oil

\begin{abstract}
A B S T R A C T
Screening of plant species with an ability to grow on contaminated soil is the most critical step in the planning of a phytoremediation program. While flourishing growth of Impatiens balsamina L. and Crotalaria retusa L. has been observed in areas adjacent to automobile service stations in Sri Lanka, no systematic study of their tolerance to used lubricating oil (ULO) contaminated soil has been carried out. Therefore, the aim of the present study was to investigate the comparative responses of $I$. balsamina L. and C. retusa L. to soil contaminated with ULO. Both species exhibited $100 \%$ seed germination in soils treated with $1 \%-5 \% \mathrm{w} / \mathrm{w}$ ULO. After $120 \mathrm{~h}$ exposure, root lengths and biomass of germinated seedlings of both species were significantly $(\mathrm{p}<0.05)$ reduced in all treatments above $3 \% \mathrm{w} / \mathrm{w}$ ULO. The measured growth parameters of plants following $90 \mathrm{~d}$ exposure to $0.5-3 \%$ $\mathrm{w} / \mathrm{w}$ ULO, indicated significant $(\mathrm{p}<0.05$ ) negative effects on I. balsamina and C. retusa at $>1 \% \mathrm{w} / \mathrm{w}$ and $>2 \%$ w/w ULO, respectively. There were no significant effects on chlorophyll content or root anatomy of either species under any treatments. Therefore, we concluded that $I$. balsamina can tolerate up to $1 \%$ of ULO and C. retusa up to $2 \% \mathrm{w} / \mathrm{w}$ ULO without displaying any negative effects. Comparatively higher biodegradation of ULO in the rhizosphere, root nodule formation, increases in root length and root hair density are all possible strategies for the exhibited higher tolerance of $C$. retusa. Therefore, the overall results indicate that $C$. retusa has the greater potential to be used in phytoremediation of ULO contaminated soils. The findings of the present study will be beneficial in planning phytoremediation program for ULO contaminated soil.
\end{abstract}

\section{Introduction}

Soil is a dynamic and complex ecosystem that plays a major role in the continuation of life on earth. Contamination of soil with used lubricating oil (ULO), as a result of anthropogenic activities such as indiscriminate disposal of ULO into gutters, water drains and vacant plots by roadside motor mechanics and allied workers has become a serious global issue (Odjegba and Sadiq, 2002; Glibovytska et al., 2019). Used lubricating oil is a mixture of hydrocarbons consisting of $73-80 \%$ aliphatic compounds, $11-15 \%$ monoaromatic, $2-5 \%$ diaromatic and $4-8 \%$ polyaromatic hydrocarbons, polar fractions and heavy metals (VazquezDuhalt, 1989). Further, ULO may persist for a long time in ecosystems (Ramadass et al., 2018). Therefore, soil contaminated with ULO may negatively affect soil physicochemical and biological properties (Okonokhua et al., 2007; Lum and Chikoye, 2018) and consequently may pose threats on terrestrial ecosystems (Ramadass et al., 2015). Therefore, an effective method is required to remediate the ULO contaminated soil.
Phytoremediation is a novel, cost effective and environmental friendly method (Malik et al., 2017; Ugwu et al., 2019) that has potential application in remediation of ULO contaminated soil (Sharifi et al., 2007). The approach has a number of technical advantages over conventional ex-situ treatment methods such as excavation, off-site storage, incineration and soil washing using surfactants, emulsifiers and additives (Chaudhry et al., 2005; Hussain et al., 2018). The most critical step in the planning of a phytoremediation program is the screening of plant species for their ability to grow on ULO contaminated soil and its success will mainly depends on the degree of resistance to hydrocarbons of the selected species (Gaskin, 2008). Previous studies have reported that the effect of ULO on the growth and tolerance of crop and ornamental plants is species-specific e.g. Capsicum annuum L. (Anoliefo and Vwioko, 1995), Abelmoschus esculentus (Agbogidi and Nweke, 2005); Medicago sativa (Liu et al., 2012) and Echinacea purpurea (Heidari et al., 2018). However, there is a scarcity of data relevant to plant species with tolerance to sites contaminated with multiple pollutants (Batty and Dolan, 2013). Hence, it is vitally important to identify different

\footnotetext{
* Corresponding author.

E-mail addresses: sumudu90.uor@gmail.com (W. Gamage), mas@bot.ruh.ac.lk (K. Masakorala), m.t.brown@plymouth.ac.uk (M.T. Brown).
} 
plant species with higher tolerance to contaminated soil with a mixture of contaminants such as ULO.

Impatiens balsamina $\mathrm{L}$. is an ornamental species of the family Balsaminaceae. It is native to India and Myanmar but has been introduced to other countries in Europe, Asia, the Americas, Australia and some parts of tropical Africa as an ornamental species. Crotalaria retusa L. is a leguminous species within the family Fabaceae. It has a worldwide distribution and widely spread in tropical Asia, Africa, America and Australia (Cabi.org, 2019). Both species are annuals that produce attractive flowers. In our preliminary studies, we observed flourishing growth and widespread dispersion of I. balsamina $\mathrm{L}$ and $C$. retusa as single stands on wastelands adjacent to automobile service stations in semi-urban areas of Sri Lanka. If abundant, ornamental plants could be used to remediate contaminated soils, with the additional advantage of enhancing the aesthetic value of the contaminated site providing therapeutic benefits to local residents (Ikeura et al., 2016). However, little attention has been paid to the suitability of ornamental plants to remediate ULO contaminated soils (Wang and Zhou, 2005), and thus further studies are required. Moreover, there are additional benefits to using leguminous plants in phytoremediation because of their ability to fix nitrogen. Thus, leguminous plants not only grow well in petroleumcontaminated soils with low availability of nitrogen (Gudin and Syratt, 1975, Wenzel 2009), they also stimulate microorganisms in the rhizosphere by releasing exudates of carbon, energy, nutrients, enzymes and sometimes oxygen from their roots (Cunningham et al., 1996; Yan-de et al., 2007; Pérez-Montaño et al., 2014). The suitability of using leguminous plants to recover petroleum-contaminated soils has been reported previously (Gudin and Syratt, 1975; Muratova et al., 2008; Inckot et al., 2011; Akhter et al., 2018).

Seed germination and seedling growth of a particular plant species in contaminated soil is an indication of the tolerance of that species (Peng et al., 2009). Chen et al. (2013) reported the importance of plant tolerance as an indication of the phytoremediation potential of a plant. Different stages in the plant life cycle might show different responses to contaminants and therefore, it is vitally important to measure a range of endpoints at different stages of development and levels of biological organization (physiological and cellular). However, comprehensive and comparative studies on seed germination and growth performance of $I$. balsamina and C. retusa in ULO contaminated soil have not been carried out to date. Therefore, the aim of the present study was to investigate the effects of ULO contaminated soil on seed germination, growth performance, root anatomy and chlorophyll contents of I. balsamina and C. retusa.

\section{Materials and methods}

\subsection{Plant material}

Five hundred mature seeds from each of I. balsamina and C. retusa were collected from plants growing in the plant-house of the University of Ruhuna, Matara, Sri Lanka. Mature seeds of the two species identifiable by the pod color; pods of $C$. retusa change from greenish to dark brown to black when mature and those of I. balsamina change from greenish to yellow when mature. Collected seeds were carefully observed for physical damages and fungal infections and apparently healthy seeds with approximately the same size were selected for experiments. A sub-sample of seeds was tested for viability using Tetrazolium/TTC test (Souza et al., 2010). According to the results both seed samples were suitable for experimentations.

\subsection{Soil sampling and preparation}

Soil was collected from the surface layer $(5-10 \mathrm{~cm})$ of an undisturbed site of the University of Ruhuna, Matara, Sri Lanka in July 2017. Following air drying, soil was passed through a $2 \mathrm{~mm} \times 2 \mathrm{~mm}$ size sieve and homogenized. This soil was used as an uncontaminated control in all experiments in this study. Prior to experimentation a physiochemical analysis of soil samples was carried out. Soil texture was determined by using a standard sieve set (Retsch AS 200 basic, RETSCH, Germany) and analyzed by using soil texture triangle (USDANRCS, 1999). The $\mathrm{pH}$ was determined with a digital $\mathrm{pH}$ meter (Eutech pH 150, Thermo Fisher Scientific India Pvt. Ltd, India) using a 1:5 w/v soil/water suspension. Gravimetric water potential (GWP) was determined by loss of weight after drying soil at $105^{\circ} \mathrm{C}$ for $24 \mathrm{~h}$, according to Black (1965). The organic matter content (OM) of the soil was determined according the loss on ignition method (LOI) following the protocol of the American Society for Testing and Materials (ASTM) standards (2014). Soil nitrate-nitrogen was determined by the $\mathrm{KCl}$ extractable method (Robertson et al., 1999) and extractable P was determined according to the method described by Murphy and Riley (1962).

Used lubricating oil (ULO) was collected from an automobile service station at Kekanadura, Matara, Sri Lanka. In order to obtain different ULO contamination levels in the soil, uncontaminated soil was spiked with ULO and homogenized to obtain $10,000 \mathrm{mg} / \mathrm{kg}(1 \% \mathrm{w} / \mathrm{w})$, $20,000 \mathrm{mg} / \mathrm{kg}(2 \% \mathrm{w} / \mathrm{w}), 30,000 \mathrm{mg} / \mathrm{kg}(3 \% \mathrm{w} / \mathrm{w}), 40,000 \mathrm{mg} / \mathrm{kg}(4 \%$ $\mathrm{w} / \mathrm{w})$ and $50,000 \mathrm{mg} / \mathrm{kg}(5 \% \mathrm{w} / \mathrm{w})$.

\subsection{Determination of seed germination and seedling growth performance}

A preliminary experiment was conducted according to the ISO method (1993) to investigate seed germination and seedling growth performance of $I$. balsamina and C. retusa in ULO contaminated soil containing $10,000 \mathrm{mg} / \mathrm{kg}, 20,000 \mathrm{mg} / \mathrm{kg}, 30,000 \mathrm{mg} / \mathrm{kg}, 40,000 \mathrm{mg} / \mathrm{kg}$ and $50,000 \mathrm{mg} / \mathrm{kg} \mathrm{w} / \mathrm{w}$ ULO. Briefly, samples of $150 \mathrm{~g}$ control and contaminated soils were placed in $150 \mathrm{~mm}$ diameter Petri dishes and soil water holding capacity was adjusted to $60 \%$. Ten seeds per Petri plate and five replicates per treatment and control were used. Following $96 \mathrm{~h}$ incubation at $25^{\circ} \mathrm{C}$ in the dark, the percentage seed germination, defined as radicle and plumule was calculated using the formula:

Percentage seed germination $(G P)=($ Number of germinated seeds $)$

$$
/(\text { Total number of seeds }) \times 100
$$

After a $120 \mathrm{~h}$ incubation period, five seedlings from each replicate were randomly selected and seedling shoot length, main root length and dry biomass of shoots and roots were measured. Shoot and root length was were measured prior to drying using a millimeter ruler and the dry weight was measured by oven drying samples to constant weight at $60{ }^{\circ} \mathrm{C}$. Percentage inhibition of seed germination, seedling height, root length and dry weight were calculated using following the formula:

Percentage inhibition $=((A-B) / A) \times 100$

where $\mathrm{A}$ is the mean of the measured parameter in the control soil and $\mathrm{B}$ is the mean of the measured parameter in the tested contaminated soil.

\subsection{Plant performance}

A pot experiment was carried out in the plant house at about $30^{\circ} \mathrm{C}$ to study early growth performance of I. balsamina and C. retusa in ULO contaminated soil. Four kilograms of prepared contaminated (5000 mg/ $\mathrm{kg}(0.5 \% \mathrm{w} / \mathrm{w}), 10,000 \mathrm{mg} / \mathrm{kg}(1 \% \mathrm{w} / \mathrm{w}), 15,000 \mathrm{mg} / \mathrm{kg}(1.5 \% \mathrm{w} / \mathrm{w})$, $20,000 \mathrm{mg} / \mathrm{kg}(2 \% \mathrm{w} / \mathrm{w}), 25,000 \mathrm{mg} / \mathrm{kg}(2.5 \% \mathrm{w} / \mathrm{w}), 30,000 \mathrm{mg} / \mathrm{kg}$ $(3 \% \mathrm{w} / \mathrm{w}))$ and uncontaminated (control) soils were placed in individual plastic pots $(17 \mathrm{~cm} \times 22 \mathrm{~cm})$ and the soil water holding capacity was adjusted to $60 \%$ and maintained during the $90 \mathrm{~d}$ experimental time period. The experiment used a randomized block design (RBD) with 4 replicates per treatment and control. In each pot two seeds of either I. balsamina or C. retusa were planted and watered regularly. 
2.5. Measurement of plant height, root length, biomass and morphological characterization of root systems

Shoot height $(\mathrm{cm})$ was measured from soil level to the tip of the shoot using a meter ruler (Omosun et al., 2008) after $30 \mathrm{~d}$ and thereafter at $30 \mathrm{~d}$ intervals. Length of the main root $(\mathrm{cm})$, shoot fresh and dry biomass $(\mathrm{mg})$ and root fresh and dry biomass $(\mathrm{mg})$ were measured and morphological characters of the root system, including root color, lateral branching, presence of root hairs in both tested species and presence of root nodules in $C$. retusa, were carefully observed in all treatments and control at the end of $90 \mathrm{~d}$ experimental period. Root length was measured using a meter rule by taking measurement from the base of plant to the tip of the longest root. Fresh and dry biomass were measured by using an electronic balance (EK - 410i $400 \mathrm{~g} \times 0.01 \mathrm{~g}$ ). Root fresh biomass was measured after washing off soil adhering to the root surface followed by blotting and air-drying for $1 \mathrm{~h}$. Dry biomass of shoots and roots were determined after oven-drying samples to constant weight at $60^{\circ} \mathrm{C}$.

\subsection{Tolerance index (Ti)}

To determine the degree of growth inhibition in $C$. retusa and $I$. balsamina grown in soil contaminated with ULO, an index of tolerance was calculated according to Szulc et al. (2010).

$T i=$ dry weight of plant grown in ULO contaminated soil $(T p)$

/dry weight of plant grown in control soil (Tn)

\subsection{Determination of chlorophyll content}

Chlorophyll $a, b$ and total chlorophyll concentrations were determined after $90 \mathrm{~d}$ following the method described by Maclachalam and Zalik (1963). Chlorophyll was extracted from the fourth leaf from the tip of the main stem. Briefly, $0.5 \mathrm{~g}$ o f leaf tissue were placed in $100 \mathrm{~mL}$ flasks containing $25 \mathrm{~mL}$ of acetone. Flasks were kept in the dark for $24 \mathrm{~h}$ and were shaken twice during incubation. The chlorophyll suspensions were centrifuged at $67,080 \times \mathrm{g}$ for $20 \mathrm{~min}$. Absorbance of the supernatant was measured at $645 \mathrm{~nm}$ and $665 \mathrm{~nm}$ using UV/Visible spectrophotometer (Evolution 260 Bio, Thermo Fisher Scientific Inc. Germany). Chlorophyll $a, b$ and total chlorophyll contents were calculated using following formulae:

$C a=(12.3 O D 663-0.860 D 645) /(d \times 1000 \times W) \times V$

$C b=(19.30 D 645-3.600 D 663) /(d \times 1000 \times W) \times V$

where $C_{a}$ is the chlorophyll a concentration $(\mathrm{mg} / \mathrm{kg} \mathrm{FW}), \mathrm{C}_{\mathrm{b}}$ is the chlorophyll $\mathrm{b}$ concentration ( $\mathrm{mg} / \mathrm{kg} \mathrm{FW}$ ), OD is the optical density, $\mathrm{V}$ is the final volume $(\mathrm{mL})$ of extract, $\mathrm{W}$ is the fresh weight of the leaf sample $(\mathrm{g}), \mathrm{d}$ is the path-length of light $(\mathrm{cm})$.

\subsection{Root anatomy}

Anatomical studies were carried out to determine whether there were any structural differences in roots of $C$. retusa and I. balsamina grown in soil contaminated with ULO compared to plants grown in control soil. Fresh root sample was collected from C. retusa and I. balsamina and washed thoroughly using distilled water. Cross sections from the middle of roots ( $10 \mathrm{~cm}$ back from the root tip) were cut using a razor blade and mounted in water and observed under the medium power (10x) of a digital photo microscope (Olympus DP 20, Olympus Cooperation, Japan).

\subsection{Percentage biodegradation of ULO}

The percentage oil biodegradation in the soil taken from the rhizosphere of tested species was determined at intervals of $30 \mathrm{~d}$ using the gravimetric method described by Agamuthu et al. (2010). Total petroleum hydrocarbon (TPH) concentrations were measured from soil with contamination levels of $1 \%, 2 \%$ and $3 \% \mathrm{w} / \mathrm{w}$ ULO. Ten grams of soil were suspended in $20 \mathrm{~mL}$ of dichloromethane in a $250 \mathrm{~mL}$ Erlenmeyer flask. After shaking for $1 \mathrm{~h}$ on an orbital shaker (Lab Companion SK 300 Benchtop shaker, GMI Inc. USA) at $200 \mathrm{rpm}$, the oil suspension was filtered through a Whatman No. 4 filter paper, the filtrate centrifuged for $20 \mathrm{~min}$ at $966 \times \mathrm{g}$ and the supernatant decanted into a clean dry beaker of known weight. This procedure was repeated 5 times for each sample in order to recover the maximum amount of oil extracted into the solvent. The solvent was completely evaporated on a water bath at $40^{\circ} \mathrm{C}$. The beaker (containing residual oil) was re-weighed and the TPH content was calculated using the following formula:

TPH content $=$ (final weight of the beaker containing residual

$$
\begin{aligned}
& \text { oil - weight of the empty beaker) } \\
& \text { /(weight of the soil sample) }
\end{aligned}
$$

Percentage biodegradation was calculated according to the following formula.

$$
\begin{aligned}
\text { Percentage biodegradation }= & {[\text { weight of oil }(\text { control })-\text { Weight of }} \\
& \text { oil }(\text { degraded })] /[\text { weight of oil }(\text { control })] \\
& \times 100
\end{aligned}
$$

\subsection{Statistical analysis}

Statistical analyses were performed using the standard statistical software MINITAB version 17. All the measured parameters were analyzed using one way ANOVA followed by Turkey's post hoc test to determine significant difference among individual means. Two way ANOVA was performed to determine the interactive effect of ULO concentration and species on plant growth performances. The statistical significant was defined at $\mathrm{p}<0.05$ and $\mathrm{p}<0.001$.

\section{Results}

\subsection{Physicochemical characterization of control soil}

According to the measured physico-chemical parameters, soil texture of the control soil was determined as sandy loam and $\mathrm{pH}$ was slightly acidic (Table 1).

\subsection{Effect of ULO on seed germination and seedling growth}

Since results showed $100 \%$ seed germination of both $C$. retusa and $I$. balsamina in all ULO contamination levels, the percentage inhibition of seed germination was zero.

After $120 \mathrm{~h}$ exposure, there was a downward trend in root length, seedling height and biomass of both species with the increasing ULO

Table 1

Physicochemical properties of uncontaminated soil (control).

\begin{tabular}{ll}
\hline Soil property & Control soil \\
\hline $\mathrm{TPH}\left(\mathrm{mg} \mathrm{kg}^{-1}\right)$ & 0 \\
Soil texture & Sandy loamy \\
Soil pH & $5.36 \pm 0.03$ \\
$\mathrm{GWP}(\%)$ & $5.37 \pm 0.04$ \\
$\mathrm{OM}(\%)$ & $14.64 \pm 0.46$ \\
$\mathrm{~N}-\mathrm{NO}_{3}^{-}\left(\mathrm{mg} \mathrm{kg}^{-1}\right)$ & $3.06 \pm 0.02$ \\
$\mathrm{P}\left(\mathrm{mg} \mathrm{kg}^{-1}\right)$ & $0.12 \pm 0.01$ \\
\hline
\end{tabular}

GWP gravimetric water potential, OM organic matter content, $\mathrm{N}-\mathrm{NO}_{3}{ }^{-}$nitrogen nitrate concentration, $\mathrm{P}$ extractable phosphorous. 

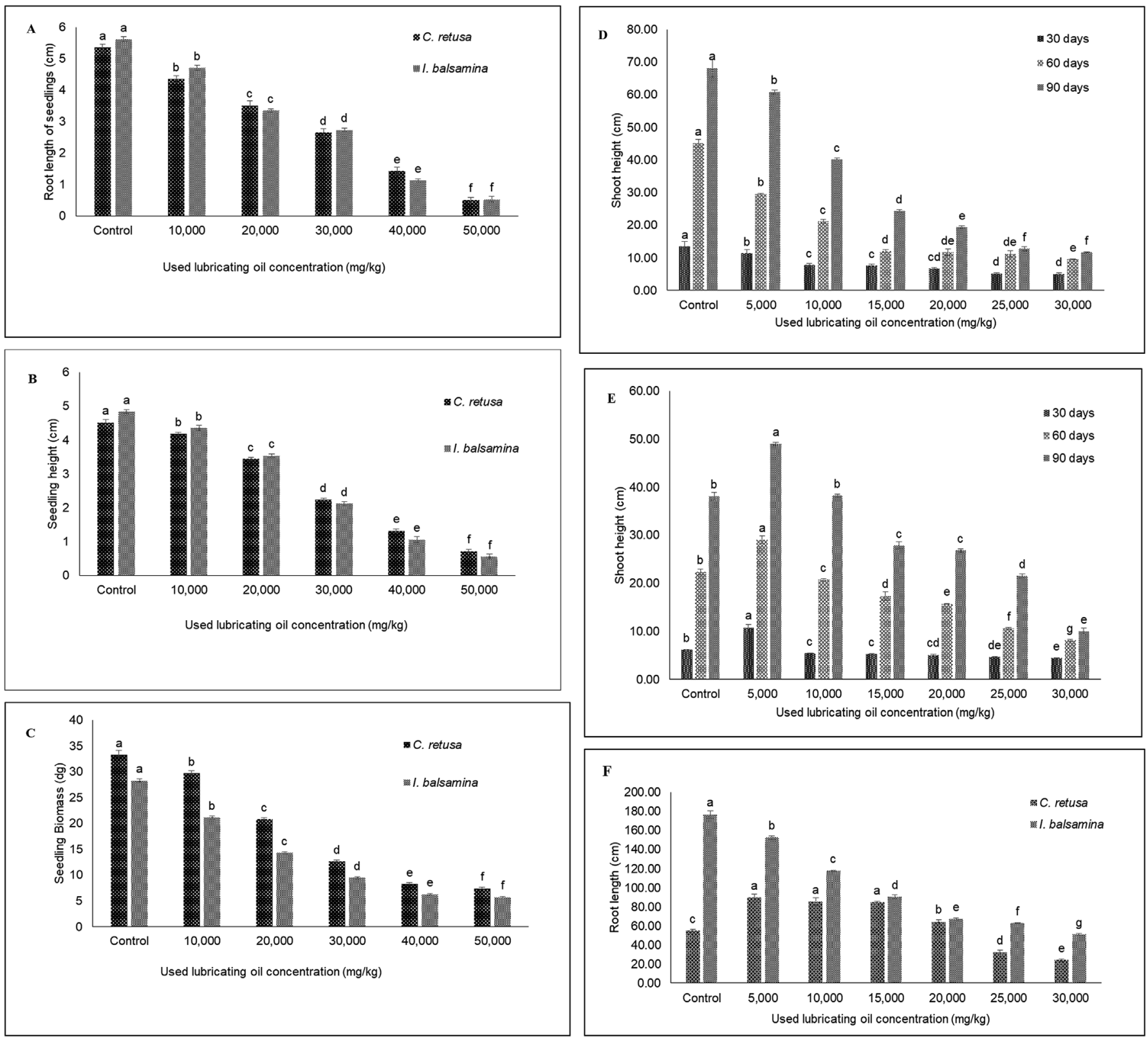

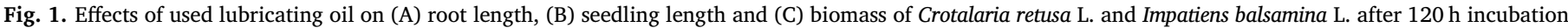

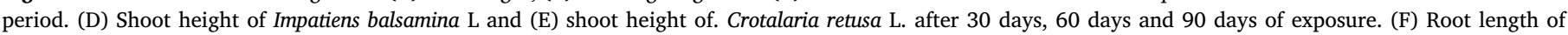

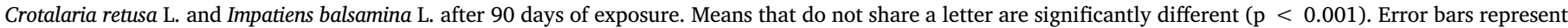
the standard deviation of three independent measurements.

concentration (Fig. 1-A, 1-B and 1-C). The root lengths of $C$. retusa and $I$. balsamina seedlings in uncontaminated control were $5.36 \mathrm{~cm}$ and $5.62 \mathrm{~cm}$, respectively compared with significantly smaller roots in the ULO contaminated soils. Mean seedling height and biomass of $I$. balsamina grown in control soil were $4.84 \mathrm{~cm}$ and $28.3 \mathrm{dg}$ respectively and the same parameters measured in C. retusa were $4.52 \mathrm{~cm}$ and $33.3 \mathrm{dg}$ respectively. At $3 \% \mathrm{w} / \mathrm{w}$ ULO, root length inhibitions was $48.88 \%$ and $49.47 \%$ of controls for C. retusa and I. balsamina respectively. For seedling height, values were $48.23 \%$ and $47.93 \%$ for $C$. retusa and $I$. balsamina respectively and for biomass inhibition were $49.43 \%$ and $48.83 \%$ for C. retusa and I. balsamina respectively. More than $50 \%$ inhibition in root length, seedling height and biomass were recorded in seedlings of both species that grew in soils contaminated with $\geq 3 \% \mathrm{w}$ / w ULO.

\subsection{Effect of used lubricating oil on plant growth performance and morphological characteristics of root system}

For I. balsamina, after $90 \mathrm{~d}$ there was a significant contamination level dependent decrease in all the measured growth parameters, shoot height, (Fig. 1-D); root length, (Fig. 1-F); shoot and root fresh and dry biomass, (Table 2). At 1\% w/w ULO, percentage inhibition values for shoot fresh biomass (46.77\%), shoot dry biomass (44.45\%), root fresh biomass (43.10\%) and root dry biomass (38.20\%) of I. balsamina were all less than $50 \%$, whereas at higher contamination levels all these parameters were inhibited by more than $50 \%$. In contrast, $C$. retusa grown in soil containing $0.5 \% \mathrm{w} / \mathrm{w}$ ULO showed growth enhancement compared to controls. The recorded percentage increases in shoot height, shoot fresh biomass, shoot dry biomass, root length, root fresh biomass and root dry biomass were $28.61 \%, 8.42 \%, 23.62 \%, 63.72 \%$, $13.39 \%$ and $6.36 \%$ (Fig. 1-E and $1-\mathrm{F}$ and Table 3), respectively. 
Table 2

Effects of Used Lubricating Oil (ULO) on shoot system biomass (fresh and dry) and root system biomass (fresh and dry) of Impatiens balsamina L. after 90 days exposure.

\begin{tabular}{lllll}
\hline $\begin{array}{l}\text { Treatment } \\
(\mathrm{mg} / \mathrm{kg})\end{array}$ & $\begin{array}{l}\text { Shoot fresh } \\
\text { biomass }(\mathrm{g})\end{array}$ & $\begin{array}{l}\text { Shoot dry } \\
\text { biomass }(\mathrm{g})\end{array}$ & $\begin{array}{l}\text { Root fresh } \\
\text { biomass }(\mathrm{g})\end{array}$ & $\begin{array}{l}\text { Root dry } \\
\text { biomass }(\mathrm{g})\end{array}$ \\
\hline Control & $53.97 \pm 0.52^{\mathrm{a}}$ & $15.14 \pm 0.26^{\mathrm{a}}$ & $26.54 \pm 0.94^{\mathrm{a}}$ & $5.47 \pm 0.05^{\mathrm{a}}$ \\
5000 & $42.56 \pm 0.41^{\mathrm{b}}$ & $12.31 \pm 0.29^{\mathrm{b}}$ & $22.10 \pm 1.08^{\mathrm{b}}$ & $4.86 \pm 0.04^{\mathrm{b}}$ \\
10,000 & $28.73 \pm 0.39^{\mathrm{c}}$ & $8.41 \pm 0.07^{\mathrm{c}}$ & $15.10 \pm 0.65^{\mathrm{c}}$ & $3.38 \pm 0.01^{\mathrm{c}}$ \\
15,000 & $12.29 \pm 0.68^{\mathrm{d}}$ & $2.25 \pm 0.04^{\mathrm{d}}$ & $5.34 \pm 0.30^{\mathrm{d}}$ & $1.17 \pm 0.02^{\mathrm{d}}$ \\
20,000 & $7.95 \pm 0.33^{\mathrm{e}}$ & $1.60 \pm 0.01^{\mathrm{e}}$ & $4.21 \pm 0.11^{\mathrm{de}}$ & $0.98 \pm 0.01^{\mathrm{e}}$ \\
25,000 & $5.17 \pm 0.04^{\mathrm{f}}$ & $1.09 \pm 0.004^{\mathrm{f}}$ & $3.06 \pm 0.11^{\mathrm{ef}}$ & $0.77 \pm 0.02^{\mathrm{f}}$ \\
30,000 & $3.67 \pm 0.03^{\mathrm{g}}$ & $0.06 \pm 0.002^{\mathrm{g}}$ & $2.34 \pm 0.22^{\mathrm{f}}$ & $0.67 \pm 0.01^{\mathrm{g}}$ \\
\hline
\end{tabular}

*Means that do not share a letter are significantly different. $(\mathrm{P}<0.001)$.

However, at ULO levels above $0.5 \% \mathrm{w} / \mathrm{w}$ there was a significant contamination-level dependent decrease in all growth parameters, except for root length. For example, at $1 \% \mathrm{w} / \mathrm{w}$ ULO, values for shoot fresh biomass, shoot dry biomass, root fresh biomass and root dry biomass were $23.10 \%, 31.16 \%, 20.35 \%$ and $18.18 \%$, respectively (Table 3 ). These values are lower than those recorded for I. balsamina at the same contamination level. In C. retusa, $>50 \%$ inhibition in the measured growth parameters was observed in plants grown in soils above $2 \% \mathrm{w} /$ w ULO contamination.

When considering the root length of $C$. retusa, there was a significance increment up to $2 \% \mathrm{w} / \mathrm{w}$ ULO levels compared to control at the end of $90 \mathrm{~d}$ experimental time. At higher contamination levels of $2.5 \%$ and $3 \% \mathrm{w} / \mathrm{w}$ ULO, inhibition of root length was observed compared to the control. The shoot height of both C. retusa and I. balsamina (Fig. 1-D and 1-E), measured every $30 \mathrm{~d}$ time interval up to $90 \mathrm{~d}$ showed a time dependent increase at ULO treatment levels. Despite a contamination-level dependent inhibition in plant performance of both species over the course of the experiment there was no evidence of plant death. All plants of both species reached maturity 90 days after sowing seeds, even at the most extreme level of ULO contamination.

There was no significant change in root color of either tested species in any of the treatment at the end of the experiment. However, increases in lateral branching, presence of root hairs and root nodule formation were all apparent in the root systems of $C$. retusa plants grown in contaminated soil up to $2 \% \mathrm{ULO} \mathrm{w} / \mathrm{w}$ compared with root systems of controls ((Fig. 2-A and 2-B).

Two way ANOVA revealed a significant effect $(\mathrm{p}<0.001)$ of ULO contamination level, species and an interaction of species and contamination level on plant growth performance of both species. Further results clearly showed that the marked increase in growth of $I$. balsamina in low level of ULO contamination level up to $1 \% \mathrm{w} / \mathrm{w}$ ULO compared to the growth performance of $C$. retusa. But higher growth performance was recorded from $C$. retusa grown in contaminated soils with contamination levels higher than $1 \%$ ULO w/w compared to the growth performance of $I$. balsamina.

\subsection{Tolerance index (Ti)}

The calculated tolerance index of both $C$. retusa and I. balsamina (Fig. 2-C) showed contamination level dependent decrease. However, Ti of $C$. retusa at each tested contamination level was higher compared to that of I. balsamina. However, higher Ti was recorded at low contamination level for both species compared to that at high contamination levels.

\subsection{Effect of ULO on chlorophyll content}

Statistical analyses (one way ANOVA) revealed no significant differences ( $\mathrm{p}<0.05$ ) in the chlorophyll $a, b$ or total chlorophyll contents in plants of either C. retusa or I. balsamina between treatments. Mean concentrations of total chlorophyll of $C$. retusa plants $(1.63 \mathrm{mg} / \mathrm{g})$ were significantly higher than those of $I$. balsamina plants $(0.88 \mathrm{mg} / \mathrm{g})$. The results obtained from two way ANOVA showed the absence of significant $(\mathrm{p}<0.05)$ interactive effect of species and contamination level on chlorophyll content (Fig. 3-A, 3-B and 3-C).

\subsection{Root anatomical study}

No differences in root anatomical features, including cell size, shape, cellular arrangement and the thickness of different types of cell layers of tissues, were observed in plants of either I. balsamina or $C$. retusa amongst treatments.

\subsection{Percentage oil biodegradation}

Percentage oil biodegradation of soil taken from the rhizosphere of the tested species showed contamination-level dependent decreases (Fig. 4). In soil with a $1 \% \mathrm{w} / \mathrm{w}$ ULO contamination level percentage biodegradation was $51.7 \%$ and $46.3 \%$ for C. retusa and I. balsamina, respectively. At $3 \%$ ULO, percentage biodegradation has dropped to $22.8 \%$ and $18.5 \%$ from soils taken from the rhizosphere of $C$. retusa and I. balsamina, respectively.

\section{Discussion}

Measuring seed germination and seedling growth can provide valuable information on the acute toxicity of contaminants to plants. The process of seed germination is a critical step in a plant's life cycle and its sensitivity to soil contaminants has been demonstrated in various studies (Banks and Schultz, 2005). Thus, the ability of seeds to germinate in contaminated soil is often used as a first step in screening the tolerance of a species to chemical pollutants (Gaskin, 2008). Therefore, the ability of $C$. retusa and $I$. balsamina seeds to germinate in soils contaminated with different levels of ULO was assessed and used as a preliminary screening for tolerance of the tested species. However, the resultant $100 \%$ germination of both species in all tested ULO-contaminated soils, including the highest contamination level of $5 \% \mathrm{w} / \mathrm{w}$ ULO, infers that ULO does not negatively impact on this process. These

Table 3

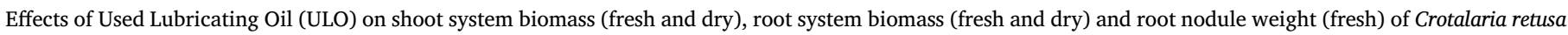
L. after 90 days exposure.

\begin{tabular}{|c|c|c|c|c|c|}
\hline Treatment (mg/kg) & Shoot fresh biomass $(\mathrm{g})$ & Shoot dry biomass $(\mathrm{g})$ & Root fresh weight biomass (g) & Root dry biomass (g) & Nodule fresh weight $(\mathrm{g})$ \\
\hline Control & $24.46 \pm 0.48^{\mathrm{b}}$ & $3.98 \pm 0.50^{\mathrm{b}}$ & $14.94 \pm 0.67^{\mathrm{b}}$ & $2.20 \pm 0.13^{\mathrm{a}}$ & $0.36 \pm 0.04^{\mathrm{a}}$ \\
\hline 5000 & $26.52 \pm 0.77^{\mathrm{a}}$ & $5.42 \pm 0.43 a$ & $16.94 \pm 0.24^{\mathrm{a}}$ & $2.33 \pm 0.06^{\mathrm{a}}$ & $1.10 \pm 0.02^{\mathrm{b}}$ \\
\hline 10,000 & $18.81 \pm 0.15^{\mathrm{c}}$ & $2.74 \pm 0.12^{\mathrm{c}}$ & $11.90 \pm 0.39^{c}$ & $1.80 \pm 0.13^{\mathrm{b}}$ & $1.01 \pm 0.02^{\mathrm{c}}$ \\
\hline 15,000 & $16.17 \pm 0.73^{d}$ & $1.87 \pm 0.04^{\mathrm{d}}$ & $8.69 \pm 0.20^{\mathrm{d}}$ & $1.55 \pm 0.06^{\mathrm{c}}$ & $0.78 \pm 0.02^{\mathrm{d}}$ \\
\hline 20,000 & $15.02 \pm 0.23^{\mathrm{d}}$ & $1.61 \pm 0.01^{\mathrm{d}}$ & $7.83 \pm 0.31^{\mathrm{e}}$ & $1.39 \pm 0.04^{\mathrm{c}}$ & $0.50 \pm 0.02^{\mathrm{e}}$ \\
\hline 25,000 & $5.56 \pm 0.67^{\mathrm{e}}$ & $0.81 \pm 0.05^{\mathrm{e}}$ & $3.72 \pm 0.07^{f}$ & $0.89 \pm 0.02^{\mathrm{d}}$ & $0.41 \pm 0.02^{\mathrm{f}}$ \\
\hline 30,000 & $3.9 \pm 0.86^{\mathrm{f}}$ & $0.39 \pm 0.01^{\mathrm{e}}$ & $1.51 \pm 0.08^{g}$ & $0.40 \pm 0.02^{\mathrm{e}}$ & $0.34 \pm 0.02^{\mathrm{a}}$ \\
\hline
\end{tabular}

*Means that do not share a letter are significantly different. 

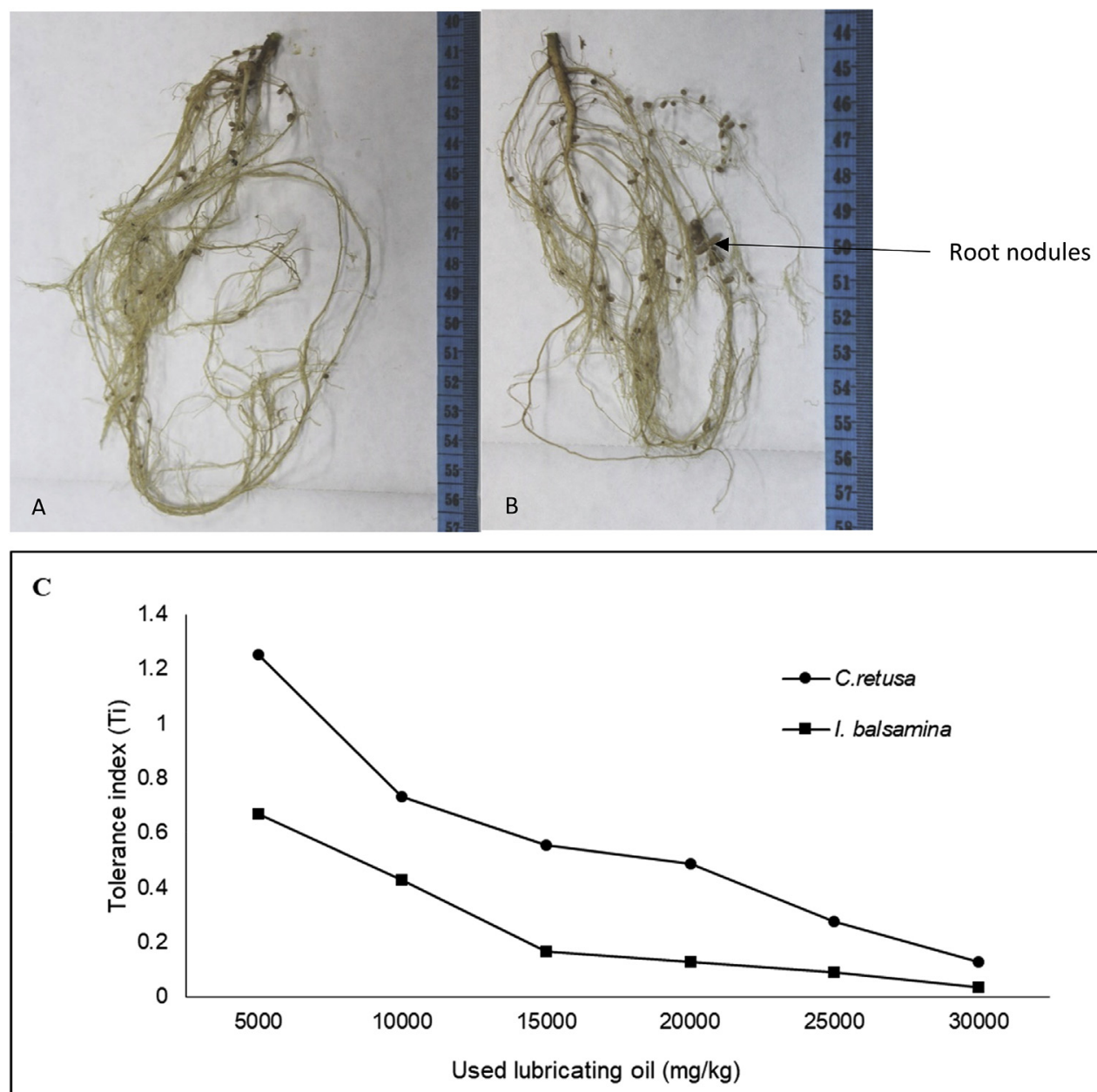

Fig. 2. Root morphology of Crotalaria retusa L. plants grown in (A) control soil (B) $0.5 \% \mathrm{w} / \mathrm{w}$ ULO. (C) Tolerance index of Crotalaria retusa L. and Impatiens balsamina L. in used lubricating oil contaminated soil.
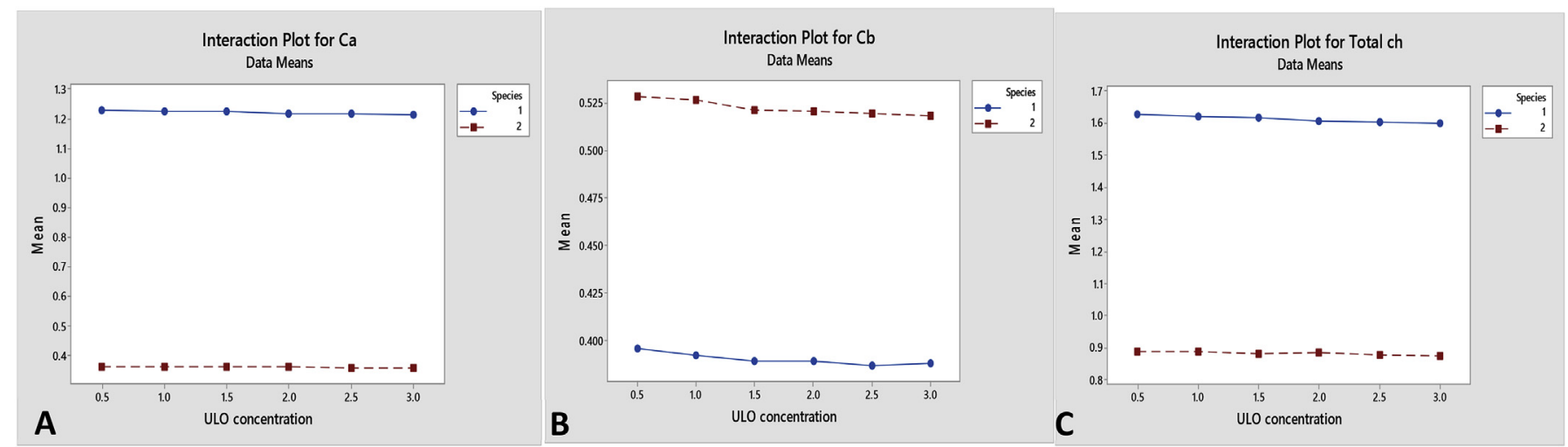

Fig. 3. Interaction plot for (A) Chlorophyll a; (B) Chlorophyll b; (C) Total chlorophyll content vs. used lubricating oil concentration (species $1=$ Crotalaria retusa; species 2 = Impatiens balsamina, $\mathrm{p}<0.001)$.

results are in agreement with those from several previous studies using soils contaminated with different types of hydrocarbons. For example, Ogbo et al. (2009) reported 100\% seed germination of Paspalum scrobiculatum L. in soils containing $0-15 \% \mathrm{w} / \mathrm{w}$ crude oil. Similarly, Odokuma and Ubogu (2014) found no reduction in germination of Phragmitis australies seeds exposed to soil contaminated with 1-6\% crude oil. In contrast, Bona et al. (2011) reported a significant reduction in seed germination of Schinus terebinthifolius in soil contaminated with diesel oil.
During seed germination, water is absorbed into the seed through the imbibition, where stored carbohydrates are hydrolyzed resulting in rapid growth of radical cells marking germination (Bewley and Black, 1994). In ULO-contaminated soils, oil may negatively influence the rate of seed germination by acting as a physical barrier that block or reduce access of water (Odokuma and Ubogu, 2014). Also, seed germination could be inhibited by hydrocarbon compounds or their metabolites that entered into the seed through imbibition due to their toxic influence or negative effect on hydrolysis (Masakorala et al., 2013a). Therefore, the 


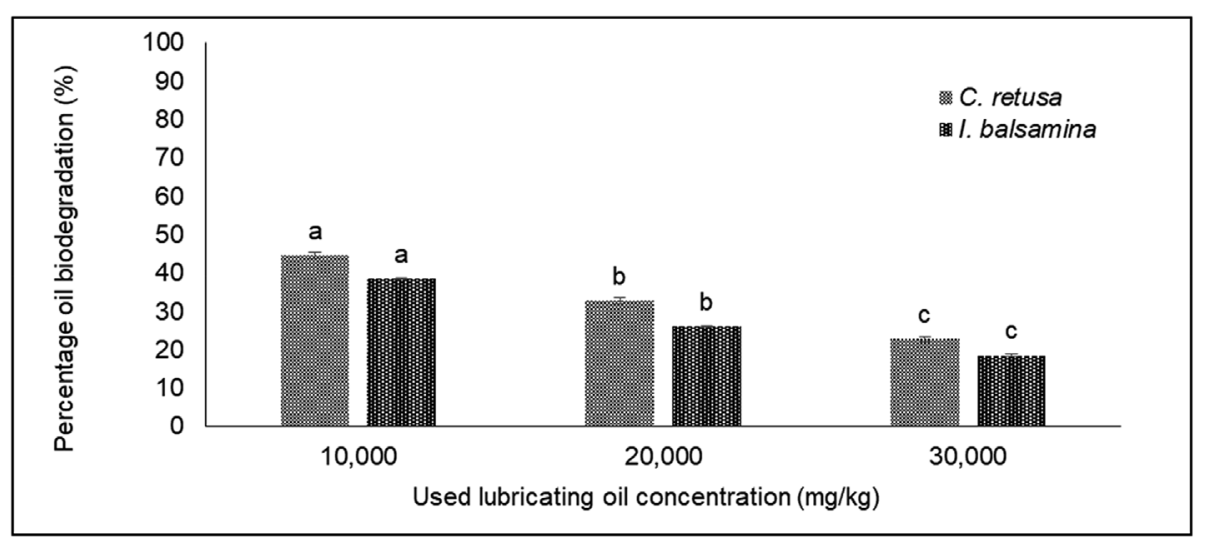

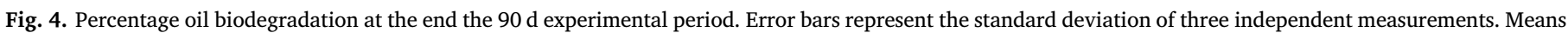
that do not share a letter are significantly different $(\mathrm{p}<0.001)$. Error bars represent the standard deviation of three independent measurements.

exhibited tolerance of $I$. balsamina and $C$. retusa seeds to ULO contaminated soil might be associated with species specific factors such as thickness and the chemistry of the seed coat. As highlighted by Adam and Duncan (2002), seed germination in soil contaminated with hydrocarbons is likely to be dependent on factors such as the type of hydrocarbon, the level of contamination and plant species. Thus, seed germination may not always be a reliable indicator of a species tolerance to soil contaminants.

Root growth parameters have relatively higher sensitivity to toxicants than percentage seed germination (Dorn et al., 1998). The root is the first organ to be fully exposed to the contaminants in soil and therefore the effects on roots are is important endpoints in evaluating plant susceptibility to soil contaminants. Root growth is a complex process involving number of biochemical and physiological processes (Masakorala et al., 2013a). The results of the present study indicated not only an inhibitory effect of ULO on early root elongation, but also on seedling height and biomass at contamination level above $3 \% \mathrm{w} / \mathrm{w}$ ULO. These findings are in agreement with previous studies on Glycine max L., Capsicum annuum, three pepper species, Vigna radiata L., Vigna unguiculata L. and Senna alata L. grown in hydrocarbon contaminated soils (Olayinka and Arinde, 2012; Njoku et al., 2008; Anoliefo and Vwioko, 1995; Obazuaye and Obueh, 2014; Akhter et al., 2018; Ugwu et al., 2019). The recorded inhibition in seedling growth might be due to combined effect of toxicity of hydrocarbon contaminants and unfavorable soil conditions developed in soil with ULO contamination.

Several studies have reported contamination-level dependent decreases in shoot length, root length, and shoot and root system biomass of plant species grown in hydrocarbon polluted soil (Anoliefo and Vwioko, 1995; Bona et al., 2011; Chupakhina and Maslennikov, 2004; Kuhn et al., 1998; Lum and Chikoye, 2018; Merkl et al., 2004; Odokuma and Ubogu, 2014; Ogbo et al., 2009; Omosun et al., 2008; Oyedeji et al., 2012; Proffitt et al., 1995; Sharifi et al. 2007). Therefore previous findings are in agreement with the results of the present study. However, typically effects of chemical are considered as negative to a test organism when a $50 \%$ reduction in the measured parameter results (Hodgson, 2004). Therefore, the recorded $<50 \%$ reduction in all measured growth parameters of I. balsamina and C. retusa grown in soils above $1 \% \mathrm{w} / \mathrm{w}$ ULO and $2 \% \mathrm{w} / \mathrm{w}$ ULO respectively compared to the plant growth in control soils infer that $I$. balsamina and $C$. retusa are able to tolerate up to $1 \%$ and $2 \% \mathrm{w} / \mathrm{w}$ ULO respectively.

As ULO forms a hydrophobic layer over the root, absorption of water and nutrients might be interrupted (Omosun et al., 2008). In addition, ULO contamination can result in anaerobic conditions in the surrounding environment and as a consequence phytotoxic compounds such as $\mathrm{H}_{2} \mathrm{~S}$ are produced by microorganisms inhabiting the soil (DeJong, 1980). Also, as oil penetrates into soil pores this can result in poor aeration, immobilization of nutrients, changes in soil $\mathrm{pH}$ and soil fertility (Shukry et al., 2013). As Shirdam et al. (2008) highlighted, plant growth can be inhibited by toxic compounds especially hydrocarbons with low molecular weight. Therefore, the reduction in growth performance of $I$. balsamina and C. retusa in ULO contaminated soils. is likely due to the combined effects of the direct toxicity of the hydrocarbon together with the unfavorable soil conditions that have developed.

Merkl et al. (2005) has reported an enhancement of growth of some plant species in soil with low level of petroleum contamination. Some plant species tend to synthesize plant growth-regulating substances as a response to the stress condition (Baker, 1970). Since C. retusa is a leguminous plant belongs to the family Fabaceae, plants are able to fix atmospheric nitrogen and restore the nitrogen pool in soil. Thus, these plants have a competitive advantage over other plants and possess a wide range of adaptations to tolerate harsh conditions. Also at low levels of contamination, diverse groups of hydrocarbon degrading microorganisms may enhance the plant growth by providing nutrients through the degradation of contaminants (Chaudhry et al., 2005; Macek et al., 2000; Martin et al., 2014). Microorganisms inhabited in the rhizosphere may decrease the production of stress hormones (Dams et al., 2007) and may increase the production of growth promoting substances at the low contamination levels. Thus the recorded growth enhancement in C. retusa in soil contaminated with $0.5 \% \mathrm{w} / \mathrm{w}$ ULO might be a result of the combined effect of the above mentioned reasons. Further investigations are necessary to establish the mechanisms involved.

The time-dependent increase in shoot growth of both $C$. retusa and $I$. balsamina grown in ULO contaminated soils reflects the overall growth enhancement. The colonization of microorganisms in the rhizospheres of $C$. retusa and $I$. balsamina with the potential to degrade ULO and produce growth promoting substances could in part be responsible for this. Further, the influence of the rhizospheric effect (RE) is strengthened by the synergistic effects of microorganisms and plant roots (Nie et al., 2010). Therefore, the observed time dependent increase in growth might be due to the time dependent reduction in toxicity levels as a result of enhancement of biodegradation of ULO with the increase in ULO degrading microbial population size in time dependent manner. Also time dependent improvement in soil physico-chemical properties parallel to the toxicity reduction might be contributing to the recorded time dependent growth enhancement.

Exposure to hydrocarbon contaminated soil can also result in changes to morphological characteristics of roots systems (ReynosoCuevas et al. 2008). Therefore, careful observations were made on root systems of both species grown in ULO contaminated soils after $90 \mathrm{~d}$ of exposure. Plants with a broader root systems are able to take up larger quantities of water and nutrients (Hutchinson et al., 2001). The population density of microorganisms in the rhizosphere is dependent on 
roots which offer substrate for growth and metabolism of microbes (Hinsinger et al., 2005). Hydrocarbon biodegradation can also be stimulated by the physical effects of plant roots such as soil aeration and the provision of sites for microbial attachment (Martin et al., 2014). Therefore, the observed increases in lateral branching of roots and the presence of root hairs in $C$. retusa be considered as an adaptive strategy for growth in soil containing up to $2 \% \mathrm{w} / \mathrm{w}$ ULO and can help explain the relative differences in tolerance between $C$. retusa and I. balsamina.

In a previous study, Agamuthu et al. (2010) observed death of $\mathrm{Ja}$ tropha curcas plants grown in $2.5 \% \mathrm{w} / \mathrm{w}$ ULO contaminated soil. However, in the present study, plants of both species survived in all treatments. Thus, we can infer from the growth performances of $I$. balsamina and $C$. retusa that both species have a greater tolerance to grow in ULO contaminated soil. C. retusa belongs to family fabaceae. Hall et al. (2011) has reported that members of family fabaceae as a well-adapted group of plant to grow on petroleum contaminated soil. Therefore, the apparently higher tolerance of $C$. retusa compared to $I$. balsamina might be due to nitrogen fixation and other intrinsic properties of $C$. retusa.

According to Bellout et al. (2016), there was a difference in cellular arrangement of roots of Pisum sativum L. grown in hydrocarbon contaminated soil. Plant may tend to produce more intercellular spaces as a response to stress posed by contaminated soil (Pezeshki et al., 2000). Also some plant species may response to water stress by increasing root diameter. When considering the root anatomical structure of both species at the age of 90 days, there were no visible differences in cell size, shape, cellular arrangement, thickness of different types of cell layers of tissues in cross section of both $I$. balsamina and $C$. retusa grown in soil contaminated with ULO compared to control plants grown in uncontaminated soil. Thus results infer that there is no stressful condition in ULO contaminated soil by the age of 90 days of both species.

Chlorophyll act as a stress biomarker in plants (More and Chaubal, 2017). Thus, chlorophyll content is considered as an important parameter to determine whether plants are in physiological stress. Previous studies have shown inhibition in chlorophyll content with increasing total petroleum hydrocarbon contamination levels (Masakorala et al., 2013b). However, as significant reductions $(P<0.05)$ in the measured chlorophyll contents at the age of $90 \mathrm{~d}$ of tested plants grown even at the highest test ULO contamination level $(3 \% \mathrm{w} / \mathrm{w})$ were not observed. Thus the results infer that both $I$. balsamina and $C$. retusa were not under stress condition at the age of $90 \mathrm{~d}$ or at the time plant enter into full mature stage in their life cycle. This might be due to combined effect of time dependent reduction in ULO through the biodegradation in the rhizosphere, time dependent improvement in soil physico-chemical parameters with reduction of ULO. Therefore, the measured chlorophyll contents further highlight the tolerance of I. balsamina and C. retusa to grow on ULO contaminated soil.

Previous studies have reported that host plants have an ability to maintain a rhizospheric microbial community with selective reactions towards contaminants by secreting specific root exudates (Berendsen et al., 2012). Bio-surfactants produced by plant roots and bacteria inhabiting in the rhizosphere may increase the bioavailability of organic pollutants (Truu et al., 2015). The expression and abundance of degrading genes in microorganisms are enhanced by the presence of particular organic compounds having structural analogy with different types of petroleum hydrocarbons in the rhizosphere (Hussain et al., 2018). Furthermore, hydrocarbon degradation in soil is increased by root exudates through making a favorable environment with good aeration and enhancing root growth and microbial activity (Hajabbasi, 2016). Thus, the higher percentage biodegradation of hydrocarbons in the rhizosphere of $C$. retusa than of $I$. balsamina might be due to species specific differences in rhizospheric effect which may have contributed higher tolerance of $C$. retusa compared to I. balsamina to grow in ULO contaminated soils. The measured time dependent increases in percentage biodegradation of ULO might be due to the time depended increases in root growth in ULO contaminated soil. Further, results infer interrelation between time dependent enhancement in growth performance and degradation of hydrocarbons which results gradual elimination of stress condition posed by ULO contaminants.

\section{Conclusion}

Seeds of both $I$. balsamina and $C$. retusa species were able to germinate in ULO contaminated soil even at contamination levels of $5 \% \mathrm{w} /$ w ULO due to species-specific tolerance of seeds. Growth performance of $C$. retusa enhanced by low ULO contamination level such as $0.5 \% \mathrm{w} /$ w. Significant reductions in measured growth parameters of $I$. balsamina and $C$. retusa were evident only at contamination levels greater than $1 \%$ $\mathrm{w} / \mathrm{w}$ ULO and $2 \% \mathrm{w} / \mathrm{w}$ ULO, respectively. Of the two species investigated, the calculated tolerance indices (based on dry biomass) indicate that $C$. retusa has a greater ability to grow in ULO contaminated soil than I. balsamina. Lateral branching and increased density of root hairs in both species and increases in root nodule formation in C. retusa, together with efficient rhizodegradation of ULO are all strategies for overcoming the toxic effects or unfavorable conditions of ULO contaminated soils. The overall results indicate the greater potential for using $C$. retusa rather than $I$. balsamina in any future phytoremediation programs to deal with ULO contaminated soil. Our findings provide valuable information for planning phytoremediation strategies for ULO contaminated soil.

\section{Acknowledgement}

Financial assistant received from the National Research Council, Sri Lanka (Grant no. 16-144) is gracefully acknowledged.

\section{References}

Adam, G., Duncan, H., 2002. Influence of diesel fuel on seed germination. Environ. Pollut. 10, 363-370. https://doi.org/10.1016/S0269-7491(02)00119-7.

Akhter, A., Iqbal, M.Z., Shafiq, M., Kabir, M., Farooqi, Z.U.R., 2018. Effects of crude oil polluted soil on the growth of legume crop species Vigna unguiculata (L.) Walp. Biosci. Res. 1 (2), 1334-1341. https://www.isisn.org/BR15(2)2018/1334-1341-15(2) 2018BR18-116.pdf.

Agamuthu, P., Abioyea, O.P., Azix, A.A., 2010. Phytoremediation of soil contaminated with used lubricating oil using Jatropha curcas. J. Hazard Mater. 179, 891-894. https://doi.org/10.1016/j.jhazmat.2010.03.088.

Agbogidi, O.M., Nweke, F.U., 2005. Effects of crude oil polluted soil on the performance of okra (Abelmoschus esculentus L.) Moench in Delta State. Am. J. Plant Sci. 8 (1), 31-35. https://doi.org/10.4236/ajps.2012.310174.

Anoliefo, G.O., Vwioko, D.E., 1995. Effects of spent lubricating oil on the growth of capsicum annuum L. and Lycopersicon esculentum Miller. Environ. Pollut. 88, 361-364. https://doi.org/10.1016/0269-7491(95)93451-5.

Baker, J.M., 1970. The effects of oil on plants. Environ. Pollut. 1, 27-44. https://doi.org/ 10.1016/0013-9327(70)90004-2.

Banks, M.K., Schultz, K.E., 2005. Comparison of plants for germination toxicity tests in petroleum-contaminated soils. Water Air Soil Pollut. 167, 11-219. https://doi.org/ 10.1007/s11270-005-8553-4.

Batty, L.C., Dolan, C., 2013. The potential use of phytoremediation for sites with mixed organic and inorganic contamination. Crit. Rev. Environ. Sci. Technol. 43 (3), 217-259. https://doi.org/10.1080/10643389.2011.604254.

Bellout, Y., Khelif, L., Guivarch, A., Haouche, L., Djebbar, R., Carol, P., Abrous Belbachir, O., 2016. Impact of edapic hydrocarbon pollution on the morphology and physiology of pea roots (Pisum sativum L.). Appl. Ecol. Environ. Res. 14 (2), 511-525. https://doi org $/ 10.15666 /$ aeer/1402 511525.

Berendsen, R.L., Pieterse, C.M., Bakker, P.A., 2012. The rhizosphere microbiome and plant health. Trends Plant Sci. 17 (8), 478-486. https://doi.org/10.1016/j.tplants 2012.04.001.

Bewley, J.D., Black, M., 1994. Seeds: Physiology of Development and Germination, second ed. Plenum Press, New York, London. https://doi.org/10.1007/978-1-48991002-8.

Black, C.A., 1965. Methods of Soil Analysis: Part I Physical and Mineralogical Properties. American Society of Agronomy, Madison,Wisconsin,USA. https://nature.berkeley. edu/soilmicro/methods/Soil\%20moisture\%20content.pdf.

Bona, C., Rezende, I.M.D., Santos, G.D.O., Souza, L.A.D., 2011. Effect of soil contaminated by diesel oil on the germination of seeds and the growth of Schinus terebinthifolius Raddi (Anacardiaceae) seedlings. Braz. Arch. Biol. Technol. 54 (6), 1379-1387. https://doi.org/10.1590/S1516-89132011000600025.

Chen, L., Liu, X., Zhang, X., Liu, S., Wei, J., Xu, G., 2013. Response characteristics of seed germination and seedling growth of Acorus tatarinowii under diesel stress. Plant Soil 368, 355-363. https://doi.org/10.1007/s11104-012-1517-8.

Chaudhry, Q., Zandstra, M.B., Gupta, S., Joner, E.J., 2005. Utilizing the synergy between 
plants and rhizosphere microorganisms to enhance breakdown of organic pollutants in the environment. Environ. Sci. Pollut. Control Ser. 12, 34-48. https://doi.org/10. 1065/espr2004.08.213.

Chupakhina, G.N., Maslennikov, P.V., 2004. Plant adaptation to oil stress. Russ. J. Ecol. 35, 290-295. https://doi.org/10.1023/B:RUSE.0000040681.75339.59.

Cunningham, S.D., Anderson, T.A., Schwab, A.P., Hsu, F.C., 1996. Phytoremediation of soil contaminated with organic pollutants. Adv. Agron. 56, 55-114.

Dams, R.I., Paton, G.I., Killham, K., 2007. Rhizoremediation of pentachlorophenol by sphingobium chlorophenolicum ATCC 39723. Chemosphere 68, 864-870. https:// doi.org/10.1016/j.chemosphere.2007.02.014.

DeJong, E., 1980. The effect of a crude oil spill on cereals. Environ. Pollut. Ecol. Biol. 22, 187-196. https://doi.org/10.1016/0143-1471(80)90013-6.

Dorn, P.B., Salanitro, J.P., Wisniewski, H.L., 1998. Assessment of the acute toxicity of crude oils in soils using earthworms, microtox, and plants. Chemosphere 37, 845-860. https://doi.org/10.1016/S0045-6535(98)00089-7.

Gaskin, B.S.E., 2008. Phytoremediation of Hydrocarbon Contaminated Soil Using Australian Native Grasses. PhD Thesis. Flinders University of South Australia. https://core.ac.uk/download/pdf/55301892.pdf.

Glibovytska, N.I., Karavanovych, K., Kachala, T., 2019. Prospects of phytoremediation and phytoindication of oil-contaminated soils with the help of energy plants. J. Ecol. Eng. 20 (7), 147-154. https://doi.org/10.12911/22998993/109875.

Gudin, C., Syratt, W.J., 1975. Biological aspects of land rehabilitation following hydrocarbon contamination. Environ. Pollut. 8, 107-112. https://doi.org/10.1016/00139327(75)90020-8.

Hajabbasi, M.A., 2016. Importance of soil physical characteristics for petroleum hydrocarbons phytoremediation: a review. Afr. J. Environ. Sci. Technol. 10 (11), 394-405. https://doi.org/10.5897/AJEST2016.2169.

Hall, J., Soole, K., Bentham, R., 2011. Hydrocarbon phytoremediation in the family Fabaceae - a review. Int. J. Phytoremediation 13, 317-332. https://doi.org/10.1080/ 15226514.2010 .495143$.

Heidari, S., Fotouhi Ghazvini, R., Zavareh, M., Kafi, M., 2018. Physiological responses and phytoremediation ability of Eastern Coneflower (Echinacea purpurea) for crude oil contaminated soil. Casp. J. Environ. Sci. 16 (2), 149-164. https://doi.org/10.22124/ cjes.2018.2957.

Hinsinger, P., Gobran, G.R., Gregory, P.J., Wenzel, W.W., 2005. Rhizosphere geometry and heterogeneity arising from root-mediated physical and chemical processes: Research review. New Phytol. 168, 293-303. https://doi.org/10.1111/j.1469-8137. 2005.01512.x.

Hodgson, E., 2004. A Text Book of Modern Toxicology, third ed. Wiley, Hoboken, pp. 221.

Hutchinson, S.L., Bank, M.K., Schwab, A.P., 2001. Phytoremediation of aged petroleum sludge: effect of inorganic fertilizer. J. Environ. Qual. 30, 395-403. https://doi.org/ 10.2134/jeq2001.302395x.

Hussain, I., Puschenreiterc, M., Gerhard, S., Schöftner, P., Yousaf, S., Wang, A., Hussain, J., Syed, H.J., Thomas, G., Reichenauera, T.G., 2018. Rhizoremediation of petroleum hydrocarbon-contaminated soils: improvement opportunities and field applications. Environ. Exp. Bot. 147, 202-219. https://doi.org/10.1016/j.envexpbot.2017.12.016.

Inckot, R.C., Santos, G.D.O., Souza, L.A.D., Bona, C., 2011. Germination and development of Mimosa pilulifera in petroleum-contaminated soil and bioremediated soil. Flora 206, 261-266. https://doi.org/10.1016/j.flora.2010.09.005.

Ikeura, H., Kawasaki, Y., Kaimi, E., Nishiwaki, J., Noborio, K., Tamaki, M., 2016. Screening of plants for phytoremediation of oil-contaminated soil. Int. J. Phytoremediation 18 (5), 460-466. https://doi.org/10.1080/15226514.2015. 1115957.

ISO, 1993. Soil Quality: Determination of the Pollutants Effect on Soil Flora. Part 1. Method for the Measurement of Inhibition of Root Growth. ISO 11269-1. International Organization for Standardization, Geneva.

Kuhn, W., Gambino, R., Al-Awadhi, N., Balba, M.T., Dragun, J., 1998. Growth of tomato plants in soil contaminated with Kuwait crude oil. J. Soil Contam. 7, 801-806. https://doi.org/10.1080/10588339891334609.

Lum, A.F., Chikoye, D., 2018. The potential of kyllinga erecta Schumach and Cyperus rotundus Linn. to remediate soil contaminated with heavy metals from used engine oil in Cameroon. Int. J. Phytoremediation 20 (13), 1346-1353. https://doi.org/10.1080/ 15226514.2018.1501339.

Liu, R., Jadeja, R.N., Zhou, Q., Liu, Z., 2012. Treatment and remediation of petroleumcontaminated soils using selective ornamental plants. Environ. Eng. Sci. 29 (6), 494-501. https://doi.org/10.1089/ees.2010.0490.

Macek, T., Mackova, M., Káš, J., 2000. Exploitation of plants for the removal of organics in environmental remediation. Biotechnol. Adv. 18, 23-34. https://doi.org/10.1016/ S0734-9750(99)00034-8.

Maclachalam, S., Zalik, S., 1963. Plastid structure, chlorophyll concentration and free amino acid composition of a chlorophyll mutant of barley. Can. J. Bot. 41, 1053-1062. https://doi.org/10.1139/b63-088.

Malik, Z.H., Ravindran, K.C., Sathiyaraj, G., 2017. Phytoremediation: a novel strategy and eco-friendly green technology for removal of toxic metals. Int. J. Agric. Environ. Res. 3, 1-18.

Martin, B.C., George, S.J., Price, C.A., Ryan, M.H., Tibbett, M., 2014. The role of root exuded low molecular weight organic anions in facilitating petroleum hydrocarbon degradation: current knowledge and future directions. Sci. Total Environ. 472, 642-653. https://doi.org/10.1016/j.scitotenv.2013.11.050.

Masakorala, K., Yao, J., Guo, H., Chandankere, R., Wang, J., Cai, M., Liu, H., Choi, M.M.F., 2013a. Phytotoxicity of long-term total petroleum hydrocarbon-contaminated soil—a comparative and combined approach. Water Air Soil Pollut. 224, 1553-1565. https://doi.org/10.1007/s11270-013-1553-x.

Masakorala, K., Yao, J., Chandankere, R., Yuan, H., Liu, H., Yu, C., Cai, M., 2013b. Effects of Petroleum hydrocarbon contaminated soil on germination, metabolism and early growth of green gram, Vigna radiata L. Bull. Environ. Contam. Toxicol. 91, 224-230. https://doi.org/10.1007/s00128-013-1042-3.

Merkl, N., Schultze-Kraft, R., Infante, C., 2004. Phytoremediation in the tropics-the effect of crude oil on the growth on tropical plants. Ann. Finance 8, 177-184. https://doi. org/10.1080/10889860490887527.

Merkl, N., Schultze-Kraft, R., Infante, C., 2005. Phytoremediation in the tropics-Influence of heavy crude oil on root morphological characteristics of graminoids. Environ. Pollut. 138, 86-91. https://doi.org/10.1016/j.envpol.2005.02.023.

More, R.S., Chaubal, S.S., 2017. Determination of stress and comparison by estimation of chlorophyll - a, b and carotenoid contents among plants growing along Mithi river, Mumbai. Int. J. Sci. Eng. Res. 8 (1). https://www.ijser.org/ onlineResearchPaperViewer.aspx?Determination-Of-Stress-And-Comparison-ByEstimation-Of-Chlorophyll-a-b-And-Carotenoid-Contents-Among-Plants-GrowingAlong-Mithi-River-Mumbai.pdf.

Muratova, A.Y., Dmitrieva, T.V., Panchenko, L.V., Turkovskaya, O.V., 2008. Phytoremediation of oil-sludge contaminated soil. Int. J. Phytoremediation 176 486-502. https://doi.org/10.1080/15226510802114920.

Murphy, J., Riley, J.P., 1962. A modified single solution methods for the determination of available phosphate in natural water. Anal. Chim. Acta 27, 31-36. https://doi.org/ 10.1016/S0003-2670(00)88444-5.

Nie, M., Xian, N., Fu, X., Chen, X., Li, B., 2010. The interactive effects of petroleum hydrocarbon spillage and plant rhizosphere on concentrations and distribution of heavy metals in sediments in the Yellow River Delta, China. J. Hazard Mater. 174, 156-161. https://doi.org/10.1016/j.jhazmat.2009.09.030.

Njoku, K.L., Akinola, M.O., Oboh, B.O., 2008. Germination, survival and growth of accessions of Glycine max L. (Merril) (Soybean) and Lycopersicon esculentum L. (tomato) in crude oil polluted soil. Res. J. Environ. Toxicol. 2 (2), 77-84 10.3923/ rjet.2008.77.84.

Obazuaye, D.O., Obueh, H.O., 2014. Study on the effect of waste engine oil on the growth of three local pepper species Capsicum frutescens, Capsicum chinense and Capsicum annuum. Asian J. Appl. Sci. 2, 678-683.

Odjegba, V.J., Sadiq, A.O., 2002. Effects of spent engine oil on the growth parameters, chlorophyll and protein levels of Amaranthus hybridus L. Environmentalist 22, 23-28. https://doi.org/10.1023/A:1014515924037.

Odokuma, L.O., Ubogu, M., 2014. Phragmitis australies growth and tolerance to crude oil contamination in mangrove swamp soil. Biorem. Biodegrad. 5 (7). https://doi.org/ 10.4172/2155-6199.1000256.

Ogbo, E.M., Zibigha, M., Odogu, G., 2009. The effect of crude oil on growth of the weed (Paspalum scrobiculatum L.)-phytoremediation potential of the plant. Afr. J. Environ. Sci. Technol. 3 (9), 229-233. https://www.ajol.info/index.php/ajest/article/view/ 46070.

Okonokhua, B.O., Ikhajiagbe, B., Anoliefo, G.O., Emede, T.O., 2007. The effects of spent engine oil on soil properties and growth of maize (Zea mays L.). J. Appl. Sci. Environ. Manag. 11 (3), 147-152. https://doi.org/10.4314/jasem.v11i3.55162.

Olayinka, B.U., Arinde, O.O., 2012. Effects of spent engine oil on germination and seedling growth of groundnut (Arachis hypogaea L.). Insight Ethnopharocology 2 (1), 5-9 10.5567/ETHNOPHARMA-IK.2012.5.9.

Omosun, G., Markson, A.A., Mbanasor, O., 2008. Growth and anatomy of Amaranthus hybridus as affected by different crude oil concentrations. Am.-Eurasian J. Sci. Res. 3 (1), 70-74.

Oyedeji, A.A., Adebiyi, A.O., Omotoyinbo, M.A., Ogunkunle, C.O., 2012. Effect of crude oil-contaminated soil on germination and growth performance of Abelmoschus esculentus L. Moench-a widely cultivated vegetable crop in Nigeria. Am. J. Plant Sci. 3 , 1451-1454. https://doi.org/10.4236/ajps.2012.310174.

Peng, W., Zhou, Q.X., Zhang, H., Shi, R.G., 2009. Responses of seed germination of 8 ornamental plants to petroleum contamination. Acta Scientiae Circumstantiae. Beijing 29, 786-790.

Pérez-Montaño, F., Alías-Villegas, C., Bellogín, R., Del Cerro, P., Espuny, M., JiménezGuerrero, I., et al., 2014. Plant growth promotion in cereal and leguminous agriculturalimportant plants: from microorganism capacities to crop production. Microbiol. Res. 169, 325-336. https://doi.org/10.1016/j.micres.2013.09.011.

Pezeshki, S.R., Hester, M.W., Lin, Q., Nyman, J.A., 2000. The effects of oil spill and clean up on dominant US gulf coast marsh macrophytes: a review. Environ. Pollut. 108, 129-139. https://doi.org/10.1016/S0269-7491(99)00244-4.

Proffitt, C.E., Devlin, D.J., Lindsey, M., 1995. Effects of oil on mangrove seedlings grow under different environmental conditions. Mar. Pollut. Bull. 30, 788-793. https:// doi.org/10.1016/0025-326X(95)00070-4.

Ramadass, K., Megharaj, M., Venkateswarlu, K., Naidu, R., 2018. Bioavailability of weathered hydrocarbons in engine oil-contaminated soil: impact of bioaugmentation mediated by Pseudomonas spp. on bioremediation. Sci. Total Environ. 636, 968-974. https://doi.org/10.1016/j.scitotenv.2018.04.379.

Ramadass, K., Megharaj, M., Venkateswarlu, K., Naidu, R., 2015. Ecological implications of motor oil pollution: earthworm survival and soil health. Soil Biol. Biochem. 85, 72-81. https://doi.org/10.1016/j.soilbio.2015.02.026.

Reynoso-Cuevas, L., Gallegos-Martinez, M.E., Cruz-Sosa, F., Gutierrez-Rojas, M., 2008. In vitro evaluation of germination and growth of five plant species on medium supplemented with hydrocarbons associated with contaminated soils. Bioresour. Technol. 99 (14), 6379-6385. https://doi.org/10.1016/j.biortech.2007.11.074.

Robertson, G.P., Coleman, D.C., Bledsoe, C.S., Sollins, P., 1999. Standard Soil Methods for Long-Term Ecological Research. Oxford University Press, pp. 106-114.

Sharifi, M., Sadeghi, Y., Akbarpour, M., 2007. Germination and growth of six plant species on contaminated soil with spent oil. Int. J. Environ. Sci. Technol. 4 (4), 463-470. https://doi.org/10.1007/BF03325982.

Shirdam, R., Zand, A., Bidhendi, G., Mehrdadi, N., 2008. Phytoremediation of hydrocarbon-contaminated soils with emphasis on the effect of petroleum hydrocarbons on the growth of plant species. Phytoprotection 89 (1), 21-29. https://doi.org/10.7202/ 000379ar. 
Shukry, W., Al-Hawas, G., Al-Moaikal, R., El-Bendary, M., 2013. Effect of petroleum crude oil on mineral nutrient elements, soil properties and bacterial biomass of the rhizosphere of jojoba. British J. Environ. Clim. Chang. 3, 103-118. https://www.cabdirect. org/cabdirect/abstract/20133276171.

Souza, C.R.D., Ohlson, O.D.C., Gavazza, M.I.A., Panobianco, M., 2010. Tetrazolium test for evaluating triticale seed viability. Rev. Bras. Sementes 32 (3), 163-169. https:// doi.org/10.1590/S0101-31222010000300018.

Szulc, W., Rutkowska, B., Labetowicz, J., Pikula, D., 2010. Tolerance index as indicator of plant sensitivity to soil pollution with heavy metals in agricultural ecosystems. Fresenius Environ. Bull. 9, 397-400. https://www.cabdirect.org/cabdirect/abstract/ 20103130442.

Truu, J., Truu, M., Espenberg, M., Nõlvak, H., Juhanson, J., 2015. Phytoremediation and plant-assisted bioremediation in soil and treatment wetlands: a review. Open Biotechnol. J. 9, 85-92. https://doi.org/10.2174/1874070701509010085.

Ugwu, E.C., Nwadinigwe, A.O., Agbo, B.C., 2019. Phytoremediation of heavy metals in spent engine oil-polluted soil by Senna alata L. bio R xiv 532887.

Vazquez-Duhalt, R., 1989. Environmental impact of used motor oil. Sci. Total Environ. 79, 1-23. https://doi.org/10.1016/0048-9697(89)90049-1.

Wang, X.F., Zhou, Q.X., 2005. Ecotoxicological effects of cadmium on three ornamental plants. Chemosphere 60, 16-21. https://doi.org/10.1016/j.chemosphere.2004.12. 031.
Wenzel, W.W., 2009. Rhizosphere processes and management in plant-assisted bioremediation (phytoremediation) of soils. Plant Soil 321, 385-408. https://doi.org/10. 1007/s11104-008-9686-1.

Yan-de, J., Zhen-li, H., Xiao-e, Y., 2007. Role of soil rhizobacteria in phytoremediation of heavy metal contaminated soil. J. Zhejiang Univ. - Sci. B 8 (3), 192-207. https://doi. org/10.1631/jzus.2007.B0192.

\section{Web references}

ASTM, 2014. Standard Test Methods for Moisture, Ash, and Organic Matter of Peat and Other Organic Soils. D2974-14. ASTM International, West Conshohocken, PA. http://gsrpdf.lib.msu.edu/ticpdf.py?file=/1990s/1993/930331.pdf.

Cabiorg, 2019. Crotalaria retusa (Rattleweed). [online] Available at: https://www.cabi. org/isc/datasheet/87408, Accessed date: 16 June 2019.

USDA-NRCS (U.S. Department of Agriculture, National Resources and Conservation Service), 1999. Guide to texture by feel. Available at: https://www.nrcs.usda.gov/ wps/portal/nrcs/detail/soils/edu/?cid=nrcs142p2_054311, Accessed date: 16 June 2019. 